\title{
Estimation of technical and allocative efficiency of cauliflower farm of Bilaspur district of Chhattisgarh state
}

\author{
Ajay Tegar \\ B.T.C. College of Agriculture and Research Station, Bilaspur (C.G.) India \\ (Email: tegar17575@gmail.com)
}

\begin{abstract}
The study analysed the technical and allocative efficiency of cauliflower farm in Bilaspur district of Chhattisgarh, using a stochastic frontier production function. Primary data were collected from 154 farmers from 04 blocks of the district. The study revealed return to scale on cauliflower farm is positive and greater than one as 2.50 which floored the farm in stage one production surface. The study also finds that variation in output of cauliflower was due to random factor. The mean technical efficiency of the pooled sample accounted to be 96.4 per cent. The two inputs land size and seed were over utilised as locative efficiency valued less than unity while other factors fertilizer, labour and irrigation were under utilised as valued greater than unity. The study recommends adoption of new method and technology in cauliflower production. The existence of under and over utilisation of resource should be addressed effectively and efficiently by extension personnel with continuous efforts making on precision farming.
\end{abstract}

Key Words : Technical, Allocative efficiency, Cauliflower farm

View Point Article : Tegar, Ajay (2021). Estimation of technical and allocative efficiency of cauliflower farm of Bilaspur district of Chhattisgarh state. Internat. J. agric. Sci., 17 (2) : 416-423, DOI:10.15740/HAS/IJAS/17.2/416-423. Copyright@2021: Hind AgriHorticultural Society.

Article History : Received : 01.03.2021; Revised : 04.03.2021; Accepted : 17.03.2021 